\title{
How does bank competition affect credit risk? Evidence from loan-level data
}

\author{
Alfredo Martín-Oliver* \\ (Universitat de les Illes Balears) \\ Sonia Ruano \\ (Banco de España) \\ Vicente Salas-Fumás \\ (Universidad de Zaragoza)
}

\section{August 2020}

\begin{abstract}
This paper studies how loan credit risk depends on competition in the banking sector. We estimate an empirical model of credit risk using data from the Spanish Credit Register on individual loans to non-financial firms in 1992-2007. Our results show that credit risk decreases with the level of competition in the credit market, and they are consistent with the prediction from the moral hazard view on the determinants of credit risk. We also find that the probability of loan default varies with characteristics of the bank, the local market and macro variables.
\end{abstract}

$J E L$ classification: $\mathrm{G} 21$

Keywords: Banks, moral hazard, credit risk, competition, product differentiation, credit register.

* Address for correspondence: Alfredo Martín-Oliver; Universitat de les Illes Balears, Ctra. Valldemossa km. 7.5, 07122 Palma de Mallorca, Islas Baleares, Spain. Tlf: + 349712599 81; e-mail: alfredo.martin@uib.es. This paper is the sole responsibility of its authors and the views represented here do not necessarily reflect those of the Banco de España. 


\section{Introduction}

Whether or not more competition in banking markets increases the risk exposure of banks and, through contagion, contributes to the fragility of the whole banking system is a relevant but unsettled research and policy question (Vives, 2016). There are two main competing views, i.e., the charter value and moral hazard, on the relation between banking competition, risk exposure of individual banks and financial stability. The charter value predicts that more intense competition in the deposits market has a negative effect on financial stability (Keeley, 1990; Hellmann et al., 2000), while the moral hazard view predicts that market competition contributes to lower credit risk and more financial stability (Stiglitz and Weiss, 1981; Caminal and Matutes, 2002; Boyd and De Nicoló, 2005). The different theoretical predictions have motivated empirical research to test which one holds in data (Kick and Prieto, 2014; Forssbæck and Shehzad, 2015). However, the different scope of analysis and the different databases complicate the comparison of the results.

This paper presents new empirical evidence on the relationship between bank risktaking behavior and bank competition, with two important novelties: the use of loan level data and the analysis of the competition effect at local-market level. First, the use of loan level data has clear advantages over bank or country level data, because granting a loan is, per se, a risk-taking decision. Second, the structural measure of market competition in our paper is the density of bank branches in spatially delimited markets, where transportation costs generate spatial differentiation that decreases with the density of branches. In doing so, we acknowledge that the relevant markets for retail banking services are local markets served by bank branches.

\section{The empirical model and hypotheses}

The econometric model to be estimated is formulated as follows:

$$
\begin{gathered}
\text { Default }_{i j p t}=\text { Compet }_{p t}^{\prime} \beta_{C}+\operatorname{Prov}_{p t}^{\prime} \beta_{P}+\operatorname{Bank}_{j t}^{\prime} \beta_{B}+\text { Macro }_{t} \beta_{E}+ \\
+\operatorname{Loan}^{\prime}{ }_{i t} \beta_{L}+\gamma_{p}+\lambda_{j}+\varepsilon_{i j p t}
\end{gathered}
$$

Default $_{i j p t}$ is a dummy that takes the value of 1 if the loan granted to firm $i$ by bank $j$ in province $p$ defaults in year $t$, and zero otherwise. The vector Compet ${ }_{p t}^{\prime}$ includes variables that capture the intensity of competition from spatial differentiation in the local market; 
$\operatorname{Prov}_{p t}^{\prime}$ includes characteristics of the borrowers in the province $p$ that capture their credit quality. Bank $k_{j t}^{\prime}$ is a vector of variables that refer to the bank $j$ that grants the loan, and Macro $_{t}$ includes variables of the general economic conditions that are common to all loans at time $t$. Loan is a vector of dummy variables that controls for the characteristics of the loan (type, maturity, collateral). The $\gamma_{p}$ and $\lambda_{j}$ are province and bank fixed effects, respectively, and $\varepsilon_{i j p t}$ is the random disturbance term. Table 1 show the definition of the main variables used in the analysis.

From the assumption of spatial positive transportation costs, higher density of branches in the province implies less spatial differentiation and more competition. Then, we can test the two competing hypotheses: Under the moral hazard (charter value) view, the probability of loan default decreases (increases) with the density of branches in the province. Since with free opening and closing of branches the density of branches is a function of the size of the market demand, the competing hypotheses are also tested with market demand variables, such as population and per-capita income.

To compare the results with those in the previous literature and highlight the relevance of the market definition and the use of loan level data, we add the concentration of banks in the market (HHI calculated with the number of branches in a province) as explanatory variable of the probability of loan default. Now, more concentration implies less competition, so the expected sign of the coefficient of $\mathrm{HHI}$ is the opposite of the sign of the density of branches.

The vector Macro $t_{t}$ includes the interbank interest rate as a relevant variable for testing the competing hypotheses. Higher market interest rate increases the loan interest rate for a given level of competition, and the moral hazard view predicts that this would increase the probability of loan default (monetary transmission). The charter value view has no direct prediction on the effect of the market interest rate, but there is an indirect effect through the deposit market. Since higher interbank interest rates increase the profits in the deposit market, the value of the charter value of the bank increases. As a result, the bank becomes more conservative and the risk-appetite of banks decreases, reducing the probability of loan default.

\section{Database}

The data on bank loans to business firms comes from the Spanish Credit Register (CIR). This unique database contains information on all bank loans granted to nonfinancial firms in Spain above the threshold of 6,000 euros. For each bank loan, we know the bank that 
granted it; the province where the borrower resides; and some loan characteristics such as the type of loan, the maturity, the guarantees, and if the loan is in default or not. We restrict our sample to loans lower than 1 million euros to focus on firms borrowing from branches in local markets, that is, $95 \%$ of the population of business loans in the CIR database. Larger loans are granted to large firms whose relevant market is likely to be the credit office of the parent bank, rather than a local market around a particular branch.

The relevant market for the retail activities of a bank is the province where it grants the loan. The data on province level variables comes mainly from the Spanish Institute of Statistics (INE). The number of branches and bank level variables come form the accounting statements that each bank reports regularly to the Banco de España. Descriptive statistics of the values of the variables of the empirical model are presented in columns three and on in Table 1.

\section{Empirical results}

The results of the estimation of different specifications of model (1) appear in Table 2. All the models are estimated with standard errors robust to heteroscedasticity and clustered at bank-province level.

Column I present the results of the estimation with the number of bank branches, $\ln N B R A N C H$, as the only market competition variable. The estimated coefficient is negative and statistically significant, consistent with the moral hazard view. The positive and significant coefficient of INTERBANK is also consistent with the prediction from the moral hazard view that higher interest rates induce higher credit risk.

The probability of loan default is also lower in provinces with higher GDP growth rate and lower UNEMPLOYMENT, that is, lower credit risk in more prosperous provinces. Loans granted by less productive banks (lower PROD) and with looser credit policies (high credit grow $L O A N G R$ and $N P L$ ) are riskier than otherwise. Finally, the capitalization of banks has a negative effect in the probability of loan default (negative coefficient of CAPITAL) indicating no evidence of substitution between financial and credit risk.

Column II includes market concentration $H H I$ and its square, HHISQ, as explanatory variables, and time dummies replace macro variables to strengthen the control for time varying effects. The estimated coefficients of $H H I$ and $H H I S Q$ are not statistically significant, and the coefficient of $\ln N B R A N C H$ increases its magnitude and statistical significance, compared to Column I. Thus, the market concentration variable strengthens, not diminishes, the competition effect of the density of branches. Controlling 
for the distribution of the number of branches across banks, an increase in the density of branches implies more branches per bank. Thus, the results indicate that the competition effect in credit risk from increasing the density of bank branches is higher when the increase is evenly distributed among banks. The results also consistent with an increase in both the number of banks and the number of branches. In fact, the correlation of the number of branches and the number of banks in the province is relatively high in the data $(88 \%)$.

Column III of Table 2 shows the results of the estimation of the model when the density of bank branches is replaced by the proxy variables of market size, GDPCAP and POPULATION (both in logs). The estimated coefficients of the two variables are negative as expected if the size of the market is a proxy of intensity of competition because they will attract the entry of larger number of branches.

\section{Conclusion}

Credit risk is at the core of the risk exposure of individual banks and, through contagion, also at the core of financial stability. The way in which competition in loan and deposit markets affects the risks taken in the lending decisions of banks is particularly important. If franchise value theory holds and more market competition induces riskier behavior by banks, then pro-competition policies and prudential banking regulation might come into conflict. In contrast, if the moral hazard view holds, market competition is aligned with safer bank loans.

The empirical results with data on individual loans granted to business firms by Spanish banks broadly support the moral hazard view that more competition decreases credit risk. More concretely, we find a negative effect of the number of branches on the probability of default, which might also be explained by the higher number of banks operating in provinces with a higher number of branches (correlation of $88 \%$ ). Bank market concentration does not directly affect credit risk, though the negative effect of the density of branches on credit risk is higher if branches are more evenly distributed among banks. The positive effect of the interbank interest rate in the probability of default also supports the moral hazard hypothesis.

The empirical results also show that banks with a higher equity ratio grant loans with a lower probability of default. There is no evidence of a trade-off between lower financial risk and higher credit risk. Rather, the empirical evidence is consistent with the prediction from the charter value that the option value of deposit insurance decreases with 
the capital ratio and for this reason more capitalized banks have lower incentives to take higher credit risks). 


\section{References}

Boyd, J. H., and De Nicolo, G. (2005). "The theory of bank risk taking and competition revisited". Journal of Finance, 60, 1329-1343.

Caminal, R. and Matutes, C. (2002). "Market power and banking failures". International Journal of Industrial Organization, 20, 1341-1361.

Forssbaeck, J. and Shehzad, C. T. (2015) "The conditional effect of market power on bank riskCross country evidence". Review of Finance, 19, 1997-2038.

Freixas, X. and Ma, K. (2015) "Banking Competition and Stability: The Role of Leverage". Center Discussion Paper Series No. 2014-048.

Hellmann, T. F., Murdock, K. C., and Stiglitz, J. E. (2000). "Liberalization, moral hazard in banking, and prudential regulation: Are capital requirements enough?" American Economic Review, 90, 147-165.

Keeley, M. C. (1990). "Deposit insurance, risk, and market power in banking". American Economic Review, 80, 1183-1200.

Kick, T. and Prieto, E. (2014) "Bank risk and competition: Evidence from regional banking markets". Review of Finance, 19, 1185-1222.

Stiglitz, J. and Weiss, A. (1981) "Credit rationing in markets with imperfect competition". American Economic Review, 71, 393-410.

Vives, X. (2016). "Competition and Stability in Banking: The Role of Regulation and Competition Policy". Princeton University Press. 
Table 1. Descriptive statistics of the main variables

\begin{tabular}{|c|c|c|c|c|c|c|}
\hline & & MEAN & SD & $\mathrm{P} 10^{\text {th }}$ & $\mathrm{P} 50^{\text {th }}$ & $\mathrm{P} 90^{\text {th }}$ \\
\hline \multicolumn{7}{|c|}{ DEPENDENT VARIABLE } \\
\hline$D E F A U L T$ & $=1$ if the loan is defaulted & 0.03 & 0.18 & 0.00 & 0.00 & 0.00 \\
\hline \multicolumn{7}{|c|}{ INDEPENDENT VARIABLES } \\
\hline \multicolumn{7}{|c|}{ Competition Variables } \\
\hline $\ln N B R A N C H$ & $\begin{array}{l}\text { Log of the number of branches in the } \\
\text { province }\end{array}$ & 6.09 & 0.93 & 5.18 & 6.10 & 6.95 \\
\hline $\ln P O P U$ & Log of the total population & 16.17 & 0.86 & 15.21 & 16.17 & 17.16 \\
\hline $\operatorname{GDPCAP}_{p}$ (th€) & $\begin{array}{l}\text { Gross Domestic Product per capita, } \\
\text { constant Euros of } 2000\end{array}$ & 17.96 & 6.69 & 9.94 & 17.11 & 27.18 \\
\hline \multicolumn{7}{|l|}{ Province Variables } \\
\hline$G D P G_{p}(\%)$ & $\begin{array}{l}\text { GDP growth at constant euros of the } \\
\text { province }\end{array}$ & 0.03 & 0.02 & 0.00 & 0.03 & 0.06 \\
\hline$U N E M P_{p}(\%)$ & Unemployment rate of the province & 0.07 & 0.02 & 0.04 & 0.07 & 0.11 \\
\hline$N P L_{p}$ & $\begin{array}{l}\text { Ratio of non-performing loans in the } \\
\text { province }\end{array}$ & 0.05 & 0.06 & 0.00 & 0.05 & 0.13 \\
\hline RURAL (\%) & $\begin{array}{l}\text { Percentage of population in villages } \\
\text { smaller than } 2000 \text { inhab }\end{array}$ & 14.95 & 14.34 & 0.67 & 11.13 & 37.01 \\
\hline \multicolumn{7}{|l|}{ Bank Variables } \\
\hline PROD & $\begin{array}{l}\text { Productivity of the bank from } \\
\text { Levinsohn and Petrin methodology as } \\
\text { in Martín-Oliver et al. (2013) }\end{array}$ & 7.58 & 0.45 & 7.03 & 7.58 & 8.19 \\
\hline $\ln A S S E T S$ & Log of the total assets of the bank & 15.55 & 1.54 & 13.60 & 15.55 & 17.69 \\
\hline$L O A N G R$ & $\begin{array}{l}\text { Yearly growth rate of the volume of } \\
\text { loans of the bank }\end{array}$ & 0.16 & 0.11 & 0.00 & 0.16 & 0.31 \\
\hline$N P L_{j}$ & Ratio of Non-performing loans & 0.05 & 0.10 & 0.00 & 0.05 & 0.13 \\
\hline CAPITAL & $\begin{array}{l}\text { Sum of equity and reserves over total } \\
\text { assets of the bank }\end{array}$ & 110.05 & 0.03 & 0.03 & 0.05 & 0.09 \\
\hline \multicolumn{7}{|c|}{ Time-varying variables } \\
\hline INTERBANK & Euribor 12 months, nominal terms & 0.06 & 0.03 & 0.02 & 0.06 & 0.11 \\
\hline$G D P G$ & $\begin{array}{l}\text { Spanish GDP growth at constant } \\
\text { euros }\end{array}$ & 0.03 & 0.01 & 0.01 & 0.03 & 0.05 \\
\hline INFLATION & $\begin{array}{l}\text { Growth rate of Consumption Price } \\
\text { Index }\end{array}$ & 0.03 & 0.01 & 0.02 & 0.03 & 0.05 \\
\hline \multicolumn{7}{|l|}{ Concentration } \\
\hline$H H I$ & $\begin{array}{l}\text { Herfindahl-Hirschman index for the } \\
\text { branch network in a province }\end{array}$ & 0.15 & 0.05 & 0.10 & 0.15 & 0.21 \\
\hline
\end{tabular}


Table 2. Determinants of Credit Risk in Bank Loans to Business Firms

\begin{tabular}{|c|c|c|c|}
\hline Dep $=1$ if Loan is Default & II & II & III \\
\hline \multicolumn{4}{|l|}{ Competition Variables } \\
\hline $\ln N B R A N C H_{t-1}$ & $\begin{array}{l}-0.017^{* *} \\
(0.008)\end{array}$ & $\begin{array}{l}-0.026^{* * *} \\
(0.010)\end{array}$ & \\
\hline $\ln P O P U_{t-1}$ & & & $\begin{array}{l}-0.025^{*} \\
(0.014)\end{array}$ \\
\hline $\ln G D P C A P_{p, t-1}$ & & & $\begin{array}{l}-0.036^{* *} \\
(0.014)\end{array}$ \\
\hline \multicolumn{4}{|l|}{ Province Variables } \\
\hline$G D P G_{p, t-1}$ & $\begin{array}{l}-0.043^{\text {*** }} \\
(0.016)\end{array}$ & $\begin{array}{l}-0.037^{* *} \\
(0.015)\end{array}$ & $\begin{array}{r}-0.023 \\
(0.017)\end{array}$ \\
\hline$U N E M P_{p, t-1}$ & $\begin{array}{c}0.096^{* *} \\
(0.047)\end{array}$ & $\begin{array}{l}0.144^{* *} \\
(0.067)\end{array}$ & $\begin{array}{c}0.119 \text { * } \\
(0.070)\end{array}$ \\
\hline$N P L_{p, t-1}$ & $\begin{array}{r}0.030 \\
(0.031)\end{array}$ & $\begin{array}{r}0.030 \\
(0.035)\end{array}$ & $\begin{array}{r}0.024 \\
(0.034)\end{array}$ \\
\hline$R U R A L_{p, t-1}$ & $\begin{array}{r}0.013 \\
(0.025)\end{array}$ & $\begin{array}{r}0.016 \\
(0.025)\end{array}$ & $\begin{array}{c}0.061 * \\
(0.034)\end{array}$ \\
\hline \multicolumn{4}{|l|}{ Bank Variables } \\
\hline $\operatorname{PROD}_{t-1}$ & $\begin{array}{l}-0.010^{* *} \\
(0.004)\end{array}$ & $\begin{array}{l}-0.010^{* * *} \\
(0.004)\end{array}$ & $\begin{array}{l}-0.009 \text { ** } \\
(0.004)\end{array}$ \\
\hline $\ln A_{S S E T S}{ }_{t-1}$ & $\begin{array}{r}0.003 \\
(0.003)\end{array}$ & $\begin{array}{r}0.003 \\
(0.004)\end{array}$ & $\begin{array}{r}0.000 \\
(0.004)\end{array}$ \\
\hline$L O A N G R_{t-2}$ & $\begin{array}{l}0.009^{* * *} \\
(0.003)\end{array}$ & $\begin{array}{c}0.005 \text { * } \\
(0.003)\end{array}$ & $\begin{array}{c}0.005 * \\
(0.003)\end{array}$ \\
\hline$L O A N G R_{t-3}$ & $\begin{array}{l}0.016^{* * *} \\
(0.003)\end{array}$ & $\begin{array}{l}0.015^{* * *} \\
(0.003)\end{array}$ & $\begin{array}{l}0.016^{* * *} \\
(0.003)\end{array}$ \\
\hline$N P L_{j, t-1}$ & $\begin{array}{l}0.424^{* * *} \\
(0.050)\end{array}$ & $\begin{array}{l}0.425^{* * *} \\
(0.052)\end{array}$ & $\begin{array}{l}0.429^{* * *} \\
(0.049)\end{array}$ \\
\hline CAPITAL $_{t-1}$ & $\begin{array}{l}-0.115^{* *} \\
(0.051)\end{array}$ & $\begin{array}{c}-0.112 \\
(0.051)^{* *}\end{array}$ & $\begin{array}{l}-0.1388^{* * *} \\
(0.048)\end{array}$ \\
\hline \multicolumn{4}{|l|}{ Time-varying variables } \\
\hline$I_{N T E R B A N K}{ }_{t-1}$ & $\begin{array}{l}0.306^{* * *} \\
(0.054)\end{array}$ & & \\
\hline$G D P G_{t-1}$ & $\begin{array}{r}0.036 \\
(0.036)\end{array}$ & & \\
\hline INFLATION $_{t-1}$ & $\begin{array}{r}0.081 \\
(0.072)\end{array}$ & & \\
\hline $\begin{array}{l}\text { Concentration } \\
H I_{p t-1}\end{array}$ & & $\begin{array}{r}0.011 \\
(0.148)\end{array}$ & \\
\hline$H_{H I S Q_{p t-1}}$ & & $\begin{array}{r}-0.396 \\
(0.389)\end{array}$ & \\
\hline Time Dummies & NO & YES & YES \\
\hline Fixed Effects & $\begin{array}{l}\text { Province, Bank, } \\
\text { Type Loan, } \\
\text { Type Collateral, } \\
\text { Maturity }\end{array}$ & $\begin{array}{l}\text { Province, Bank, } \\
\text { Type Loan, } \\
\text { Type Collateral, } \\
\text { Maturity }\end{array}$ & $\begin{array}{l}\text { Province, Bank, } \\
\text { Type Loan, } \\
\text { Type Collateral, } \\
\text { Maturity }\end{array}$ \\
\hline N.Observations & $3,681,057$ & $3,681,057$ & $3,681,057$ \\
\hline
\end{tabular}

The *,**, and $* * *$ represent significance at the $10 \%, 5 \%$, and $1 \%$ levels respectively. The $t$-ratios are in parentheses. Note: The dependent variable is a dummy that takes the value of one if the loan defaults and zero otherwise. The models are estimated with linear probability models that control for fixed effects, and the standard errors are robust to heteroscedasticity and are clustered at the bank-province level. Definitions for the variables are in Table 1 